\title{
Mobile Technologies That Help Post-Secondary Students Succeed: A Pilot Study of Canadian and Israeli Professionals and Students With Disabilities
}

\author{
Catherine Fichten ${ }^{1,2,3,4}$, Mary Jorgensen ${ }^{2}$, Laura King ${ }^{2,5}$, Alice Havel ${ }^{1,2}$, Tali Heiman ${ }^{6}$, Dorit Olenik-Shemesh ${ }^{6} \&$ \\ Dana Kaspi-Tsahor ${ }^{6}$ \\ ${ }^{1}$ Dawson College, Montreal, Canada \\ ${ }^{2}$ Adaptech Research Network, Montreal, Canada \\ ${ }^{3}$ McGill University, Montreal, Canada \\ ${ }^{4}$ Jewish General Hospital, Montreal, Canada \\ ${ }^{5}$ Cégep André-Laurendeau, Montreal, Canada \\ ${ }^{6}$ The Open Uinversity of Israel \\ Correspondence: Catherine Fichten, Adaptech Research Network, Montreal, QC, H3Z 1A4, Canada. Tel: \\ 1-514-931-8731 ext: 1546. E-mail: catherine.fichten@mcgill.ca
}

Received: August 24, 2019

doi:10.5430/irhe.v4n3p35
Accepted: September 10, 2019

Online Published: September 17, 2019

URL: https://doi.org/10.5430/irhe.v4n3p35

\begin{abstract}
In this preliminary investigation we examine the uses of mobile devices such as smartphones, tablets and laptops for (a) non-academic and (b) academic purposes in the post-secondary classroom, as well as for (c) academic tasks outside the class by post-secondary students with disabilities. Integration of smartphones and other mobile devices into the learning process is innovative, challenging and highly relevant for post-secondary education. Also, research shows that post-secondary students like courses where use of their personal mobile devices in class is allowed. To explore how students with disabilities use their mobile devices we held four focus groups, with six to eight participants each: two in Canada (one for students with disabilities, one for professionals who assist students with disabilities) and two in Israel. The findings show that students with disabilities use their mobile devices for all the same reasons as nondisabled students. In addition, students with disabilities use general purpose mobile device features and apps as assistive aids. Implications of the blurring of the distinction between assistive and general use mobile device features and apps for the academic inclusion of post-secondary students with disabilities is discussed. It appears that for many students with disabilities, access to their personal mobile devices for academic purposes, both in and out of the classroom, is essential to ensure their full inclusion.
\end{abstract}

Keywords: mobile technologies, post-secondary students with disabilities, Canada, Israel

\section{Introduction}

"I wish my professors would format documents so I can read and annotate them on my iPad," a student with limited use of her arms and hands told us. "I can take better notes on a keyboard than by hand," stated a doctoral student with a learning disability. "Now I can actually see the presentation," exclaimed a student with low vision after she downloaded the professor's PowerPoint onto her mobile device. "I can take lecture notes and read course material by listening to them on my smartphone," a student who is blind stated. Indeed, these students' comments reflect the usefulness of mobile technologies for students with disabilities but they by no means capture the complexity of the situation.

\subsection{Mobile Technologies in Higher Education}

Mobile devices have become an integral part of students' personal and academic lives. For example, Belardi (2015) found that $81 \%$ of post-secondary "students use mobile devices (such as smartphones and tablets) to study, the second most popular device category behind laptops.” Advantages of mobile devices include, among others, device portability, user mobility, ability to read directly on the device, taking photos, benefiting from instant playback, as well as being able to do video and audio recording. Because of abundant learning tools, apps, digital books with interactive elements, visual content, cameras and browsers, students can engage in learning activities with few space and time restrictions 
(Fichten et al., 2019). Most academic institutions provide free access to wireless networks, thus making the use of mobile devices inexpensive, convenient and easy to use. Indeed, the American publication EDUCAUSE (2019) expects university-wide implementation of mobile learning tools within the next two years.

Nissan (2016) reported that $90 \%$ of Israelis use a smartphone, $84 \%$ use a laptop and $53 \%$ use a tablet daily. Based on a survey as early as 10 years ago, Hammer et al. (2010) reported that $100 \%$ of Israeli post-secondary students own a smartphone, and over 90\% own a laptop. Moreover, a recent EDUCAUSE survey (Brooks \& Pomerantz, 2017) found that $97 \%$ of 35,760 American students, from 110 different post-secondary institutions, owned a smartphone and Chmiliar and Anton (2018) demonstrated 100\% smartphone ownership in their study of 46 post-secondary students with disabilities and a matched sample of 46 students without disabilities. As reported in the Horizon Report (Adams-Becker et al., 2017), mobile technologies such as smartphones, tablets and laptops are ubiquitous in today's post-secondary environment and are enthusiastically being used by students with and without disabilities.

While there are numerous lists available of the uses of smartphones by students (e.g., Leyden, 2018), the literature on the academic use of mobile technologies is relatively sparse and focused mainly on mobile technologies used by faculty (cf. Crompton \& Burke, 2018). Moreover, the literature is replete with non-academic uses of smartphones and other mobile devices in post-secondary classrooms, including texting, and using Snapchat, Facebook, Instagram, e-mail, and playing solitaire (Baker, Lusk, \& Neuhauser, 2012; Fichten, Havel, Jorgensen, King, \& Harvison, 2019; Hammer, et al., 2010).

In spite of cautions in the literature about the negative impact on grades and learning as a result of multitasking during lectures (Hammer et al., 2010; Kuznekoff \& Titsworth, 2013; Wood et al., 2011), students both in Israel (Malka, Ariel, Avidar, \& Chen Levy, 2014) and Canada generally embrace the integration of mobile technologies into the classroom. Research findings (Alkahtani et al., 2016; Baker et al., 2012) consistently show that students appreciate it when their professors allow them to use their personal technologies in class. For example, in one study, 311 Canadian post-secondary students, seventy-five of whom self-reported a disability, completed a questionnaire on their use of information and communication technologies (Fichten et al., 2015). The results show that when it comes to personal mobile technologies, virtually all students, both those with and without disabilities, like to use their personal devices in class. Yet many of their professors do not allow this (see Figure 1).

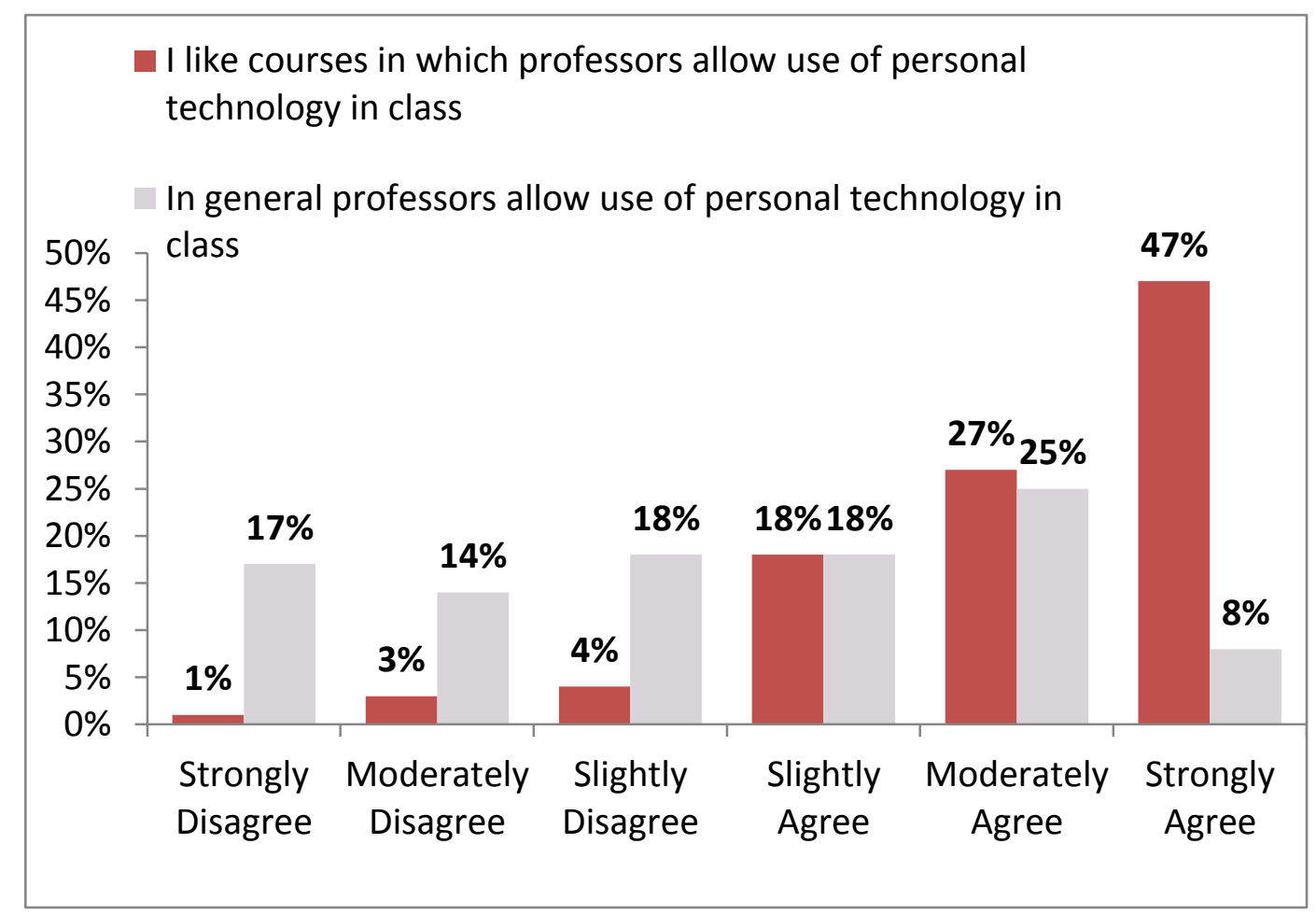

Figure 1. Student views: Use of personal technologies in class

Description: Comparison of the percentage of students (a) who indicated that they liked courses in which professors allowed them to use their personal mobile devices and the percentage of those (b) who indicated that their professors allowed them to use these mobile devices. 
In some cases professors simply ban mobile devices in the classroom. This practice, however, leaves out students who require their mobile devices to assist in their learning, such as students with diverse disabilities. Banning mobile devices for all students except those with disabilities, however, "brings up issues of equity - singling out those who need devices" and forcing "the student to choose privacy over learning" (The Room 241 Team, 2018). Indeed, in Ontario, Canada's largest province, it is illegal to ban mobile devices for all students except those with disabilities because it violates the rights of students to keep their disability private (University of Waterloo, undated), a view that is echoed elsewhere in Canada as well (Gooblar, 2014).

During the past 20 years the movement toward Universal Design in Higher Education (UDHE) has been gaining ground. A key proponent of the movement is Sheryl Burgstahler of DO-IT at the University of Washington. She defined UDHE as follows: "The design of products \& environments in higher education to be usable by all people, to the greatest extent possible, without the need for adaptation or specialized design" (Burgstahler, 2019). The goal of UD is to create more inclusive environments for all learners, eliminating the need for most accommodations or for retrofitting. Two views predominate: Universal Design of Instruction (UDI) (McGuire, Scott, \& Shaw, 2003; Scott, Loewen, Funckes, \& Kroeger, 2003) and Universal Design for Learning (UDL) (CAST, 2018). The objective of the 9 principles of UDI is to design educational environments and instruction to be accessible to all learners without the need for modifications or accommodations. Universal Design of Learning (UDL) is concerned with multiple pathways for students to learn, interact with peers and faculty, and demonstrate what they have learned (Black, Weinberg, \& Brodwin, 2015). In recent work Ableser and Moore (2018) and Thomson, Fichten, Budd, Havel, and Asuncion (2015) have combined the two approaches. Regrettably, relatively few papers have dealt with UD and mobile technologies. Exceptions are papers dealing with K-12 education (e.g., Reid, Strnadovà, \& Cumming, 2013) which looked at students with dyslexia and the paper by Xie, Basham, Marino, and Rice (2018) which reviewed 47 K-12 studies. Other than the semi-anecdotal article by Tobin (2016) and the specialized paper on MOOCs (Park, Kim, \& So, 2016), we have been unable to find universal design and mobile technology articles relevant to the post-secondary education of students with disabilities.

\subsection{Students With Disabilities in Higher Education}

It is generally estimated that well over $11 \%$ of the American and Canadian undergraduate population have a disability (Fichten et al., 2018; Snyder, de Brey, \& Dillow, 2016). Similar percentages (i.e., $12 \%$ ) have been reported in other countries, such as England (Advance HE, 2018). Indeed, a recent very large American study of freshmen enrolled in 184 different four-year colleges reported that $21.9 \%$ of students self-reported a disability (Eagan et al., 2017). Similarly, in a recent study of two-year Canadian college social science students, Fichten et al. (2019) found that $26 \%$ self-reported a disability. Approximately half of the students who self-reported a disability had not registered for campus-based access services and, therefore, were ineligible to receive disability related accommodations.

In Israel, there is no national database enumerating persons with disabilities and no national data source regarding the context of inclusion in higher education. Based on reports of universities and colleges, the proportion of students with disabilities is between $10 \%$ and $15 \%$. For example, the government committee on the inclusion of students with disabilities in colleges and universities reported that $14 \%$ to $15 \%$ of students had a disability (State of Israel, Ministry of Justice Report, 2012). Data from The Open University of Israel (2018) showed that during the 2018 academic year, $9.93 \%$ of students had single or multiple disabilities, including hearing impairments, visual impairments, physical or motor disabilities, chronic illness, psychiatric problems, learning disabilities, and attention deficit hyperactivity disorder.

A decade ago, the most common disabilities of students were visual, hearing, and mobility impairments. Currently, in North America the most common disabilities include attention deficit hyperactivity disorder, psychiatric disabilities, learning disabilities, and chronic illness (Gagné \& Tremblay, 2019). Students with these disabilities are less likely to register for disability related access services than those with more visible disabilities. For example, in a comparative study of students with learning disabilities and attention deficit hyperactivity disorder, Fichten et al. (2016) found that $64 \%$ of Israeli and $44 \%$ of Canadian post-secondary students had not registered for disability-related services. This has important implications for the use of mobile devices in post-secondary classrooms.

When it comes to assistive technologies in post-secondary education, we know a great deal about apps and software that work on Windows and Mac desktop computers. However, little is known about how mobile technologies are used to do academic work, both in class and at home, especially by students with diverse disabilities. Two notable exceptions are studies done by Clouder et al. (2019), who investigated the uses of mobile technologies by students 
with disabilities for non-academic activities and peer support, and that done by Chmiliar and Anton $(2017,2018)$, who examined the use of mobile technologies by distance education students with and without disabilities. Nevertheless, some universities in India have started to give smartphones to their students with disabilities (Chettri, 2016).

Professionals who assist students with disabilities are a group which is rarely studied. They include individuals such as information technology specialists, educational technologists, assistive technologists, and learning specialists (Jorgensen, Fichten, King, \& Havel, 2018; Asuncion et al., 2010). Examining the perspectives of professionals can help gain a more in-depth understanding of how mobile technologies can be used in the classroom to facilitate the academic success of students with disabilities.

\subsection{Present Study}

To obtain preliminary information about the potential uses of mobile technologies by students with disabilities we conducted focus groups with students with diverse disabilities and with the professionals who often work with them in two countries: Canada and Israel. The two countries are dissimilar in many ways that impact on education. What the two countries do have in common is the extensive use of technologies in post-secondary education, significant numbers of post-secondary students with disabilities, and concern with the successful academic outcomes of these students. Here we report on a comparison of Canadian and Israeli students with disabilities, along with the professionals who provide services for them.

\section{Method}

\subsection{Participants}

Canadian participants were seven students with disabilities ( 5 females, 2 males) and nine professionals (6 females, 3 males). Israeli participants were eight students with disabilities ( 3 females, 5 males) and six professionals ( 4 females, 2 males).

\subsection{Measures}

\subsubsection{Demographics}

Students self-reported their disabilities. In the Canadian sample these included attention deficit hyperactivity disorder, chronic health problems, psychiatric disabilities, and learning disabilities. Israeli students' disabilities included cerebral palsy, blindness, learning disabilities, attention deficit hyperactivity disorder, autism spectrum disorder, communication disorder, and quadriplegia. In the Canadian sample all students were studying social science in a two-year post-secondary institution. Five of the Israeli students were also studying social science, while three were studying in other programs (mathematics, physics, literature). They were enrolled in a four-year post-secondary institution. All Canadian and Israeli students had completed at least one semester of studies and were currently registered in a variety of courses taught by diverse professors. The Canadian and Israeli professionals worked in the office of academic development, information technologies, academic skills center and the student accessibility center.

\subsubsection{Focus Group Questions}

Questions centered on what mobile technologies and apps students use in the classroom and what personal mobile devices and apps students use for school work outside the classroom.

\subsection{Procedure}

The Canadian team conducted four 75-minute focus groups in November 2018 and the Israeli team did the same three months later, early in 2019. The protocol was approved in Canada by the Dawson College Research Ethics Board and in Israel by The Open University of Israel Ethics Committee. Students who had completed at least one semester of studies were recruited by e-mail. Each participant was required to sign a consent form prior to the focus group meeting. Focus group dialogue was not recorded; instead two note-takers were present. Participants were provided with digital versions of the questions and the consent form before the focus group meeting and with paper versions when the focus group met.

\section{Results}

\subsection{Mobile Devices}

Mobile devices used by students in Canada include smartphones, laptops and tablets, with several students noting that they used all three. Several students said that all their apps were installed on all their devices so that they could work seamlessness on whatever device was most convenient. Several Canadian students noted that laptops are just 
too heavy to take to class. Virtually all Canadian participants said they took their smartphones to class. Consistent with this, a professional, holding up a smartphone said, "Phones are just computers with a phone app." Israeli students used smartphones, laptops and tablets as well, but they also used MP3 players and tape recorders to record lectures in class.

\subsection{Inappropriate Uses of Mobile Devices in Class}

Some Canadian professionals noted that students with and without disabilities differed in the inappropriate uses of their devices. Nevertheless, professionals, both Canadian and Israeli, did not distinguish between students with and without disabilities in the rest of their responses.

Table 1 shows that Canadian and Israeli students and professionals indicated that mobile devices, usually smartphones, are used to text, check Facebook and other means of alleviating boredom. For example, both Canadian and Israeli professionals noted that students used their devices to check WhatsApp. In addition, Canadian professionals believed that students used their devices to check the course management system and Snapchat (Note 1), and to shop online. Israeli students and professionals, along with Canadian students, indicated that students used their devices to look up random information on Google and check to-do-lists, sometimes using an app (e.g., Todoist (Note 2)). Israeli students also said that they shop online during class and check WhatsApp. Some inappropriate uses that both groups of students reported, that were not mentioned by professionals, include playing computer games and doing homework for other classes.

Table 1. Inappropriate uses of mobile devices and apps in class

\begin{tabular}{|c|c|c|c|c|}
\hline \multirow[t]{2}{*}{ Inappropriate Uses in Class } & \multicolumn{2}{|c|}{ Canada } & \multicolumn{2}{|c|}{ Israel } \\
\hline & Students & Professionals & Students & Professionals \\
\hline Text & $\mathrm{X}$ & $\mathrm{X}$ & $\mathrm{X}$ & $\mathrm{X}$ \\
\hline Check Facebook & $\mathrm{X}$ & $\mathrm{X}$ & $\mathrm{X}$ & $\mathrm{X}$ \\
\hline Check course management system & $\mathrm{X}$ & $\mathrm{X}$ & $\mathrm{X}$ & \\
\hline Do homework for other classes & $\mathrm{X}$ & & $\mathrm{X}$ & \\
\hline Check Todoist (an app that creates a to-do list) & $\mathrm{X}$ & & $\mathrm{X}$ & $\mathrm{X}$ \\
\hline Use Google Search to look up "random" things & $\mathrm{X}$ & & $\mathrm{X}$ & $\mathrm{X}$ \\
\hline Play computer games (e.g., solitaire) & $\mathrm{X}$ & & $\mathrm{X}$ & \\
\hline Check WhatsApp & & $\mathrm{X}$ & $\mathrm{X}$ & $\mathrm{X}$ \\
\hline Use device for a "reset" when bored in class & & $\mathrm{X}$ & $\mathrm{X}$ & \\
\hline Share recordings of lectures & & $\mathrm{X}$ & $\mathrm{X}$ & \\
\hline Shop online / book vacations & & $\mathrm{X}$ & $\mathrm{X}$ & \\
\hline Check Snapchat & & $\mathrm{X}$ & & \\
\hline Take photos of corrected exams (to help cheat) & & $\mathrm{X}$ & & \\
\hline
\end{tabular}

Professionals also believed that students used their mobile devices for more nefarious purposes. Canadian professionals said that students used their devices to take photos of corrected exams to help them cheat. Although Canadian students did not report doing this, Israeli students and Canadian professionals did say that mobile devices were used to share recordings of lectures. Students did not always ask for the teacher's permission to record the lecture.

\subsection{Appropriate Uses of Mobile Devices in Class}

Table 2 shows that both Canadian and Israeli students indicated recording lectures, using their device to view projected lecture PowerPoints instead of looking at these on the classroom screen, and using Google to look up concepts related to the lecture. It is noteworthy that although both groups of professionals also noted lecture recording and Googling course relevant topics, neither group mentioned that students might download the course PowerPoint and follow along on their own device. 
Table 2. Appropriate uses of mobile devices and apps in class

\begin{tabular}{|c|c|c|c|c|}
\hline \multirow[t]{2}{*}{ Appropriate Uses in Class } & \multicolumn{2}{|l|}{ Canada } & \multicolumn{2}{|l|}{ Israel } \\
\hline & Students & Professionals & Students & Professionals \\
\hline $\begin{array}{l}\text { Use Google Search to look up concepts related to } \\
\text { course materials or to answer questions }\end{array}$ & $\mathrm{X}$ & $\mathrm{X}$ & $\mathrm{X}$ & $\mathrm{X}$ \\
\hline $\begin{array}{l}\text { Record lectures (e.g., Voice Memos, Easy Voice } \\
\text { Recorder) }\end{array}$ & $\mathrm{X}$ & $\mathrm{X}$ & $\mathrm{X}$ & $\mathrm{X}$ \\
\hline $\begin{array}{l}\text { Take pictures of diagrams and formulas on } \\
\text { blackboard or whiteboard }\end{array}$ & $\mathrm{X}$ & $\mathrm{X}$ & $\mathrm{X}$ & $\mathrm{X}$ \\
\hline Take notes in class & $\mathrm{X}$ & $\mathrm{X}$ & $\mathrm{X}$ & $\mathrm{X}$ \\
\hline $\begin{array}{l}\text { Participate in class groups to share course-related } \\
\text { information (e.g., Google Docs for group work) }\end{array}$ & $\mathrm{X}$ & $\mathrm{X}$ & $\mathrm{X}$ & $\mathrm{X}$ \\
\hline Take pictures of PowerPoint slides & $\mathrm{X}$ & $\mathrm{X}$ & $\mathrm{X}$ & \\
\hline Use Google Translate & $\mathrm{X}$ & $\mathrm{X}$ & $\mathrm{X}$ & \\
\hline Check the time & $\mathrm{X}$ & $\mathrm{X}$ & $\mathrm{X}$ & \\
\hline Follow along with the PowerPoint in class & $\mathrm{X}$ & & $\mathrm{X}$ & \\
\hline View high resolution images & $\mathrm{X}$ & & $\mathrm{X}$ & \\
\hline $\begin{array}{l}\text { Respond to professor-initiated activities (e.g., } \\
\text { Kahoot, Poll Everywhere, course management } \\
\text { system) }\end{array}$ & $\mathrm{X}$ & $\mathrm{X}$ & & $\mathrm{X}$ \\
\hline Access a dictionary or thesaurus & $\mathrm{X}$ & $\mathrm{X}$ & & \\
\hline $\begin{array}{l}\text { Complete online quiz on the course management } \\
\text { system }\end{array}$ & $\mathrm{X}$ & & & \\
\hline Do calculations & & & $\mathrm{X}$ & \\
\hline Take notes using PowerPoint on laptop & & $\mathrm{X}$ & & \\
\hline Use digital books / e-books in class & & $\mathrm{X}$ & & \\
\hline $\begin{array}{l}\text { Use in active learning classrooms to communicate } \\
\text { with interactive whiteboards (e.g., Smart Boards) }\end{array}$ & & $\mathrm{X}$ & & \\
\hline Use for peer evaluation & & & & $\mathrm{X}$ \\
\hline Use augmented reality & & & & $\mathrm{X}$ \\
\hline
\end{tabular}

All participants noted that students used their devices to take pictures of diagrams and formulas on the blackboard or whiteboard, take notes in class and engage in group activities in class using apps such as Google Docs. Although Canadian students and professionals, as well as Israeli students, mentioned using mobile devices to take pictures of PowerPoint slides, this was not mentioned by Israeli professionals. It is surprising that while Canadian students and professionals, as well as Israeli professionals, mentioned that students use their devices for class activities such as responding to the professor's questions using polling software, Israeli students did not mention this.

Canadian and Israeli students and Canadian professionals noted that students used Google to do translations in class. However, only Canadian students and professionals reported the use of online dictionaries and thesauruses by students. Both Canadian and Israeli students reported the use of mobile devices to view high resolution images. Canadian students also mentioned using their mobile devices to complete quizzes on the course management system. Interesting items reported by Israeli professionals include the use of peer evaluation and of augmented reality. Canadian professionals noted that students use e-books in class, that they use mobile devices to communicate with 
interactive whiteboards (e.g., Smart Boards) in active learning classrooms, and that they take notes directly onto PowerPoint slides on their devices.

Students and professionals described apps to help students focus in class and to manage anxiety and panic attacks, as well as apps for students with low vision and with literacy challenges. These are listed in Table 3.

Table 3. Use of assistive technologies noted by participants

\section{To Help Students Focus}

- Forest (Note 3) - app in which the student plants a virtual tree that continues to grow if they do not use their smartphone. If they use their device, the tree dies.

- Focus Lock (Note 4) - app that locks specific applications on the smartphone for a set amount of time.

- Mindly (Note 5) - app that allows students to create schematic maps of their ideas.

- Notification system on device - turn it off (no alerts or reminders)

- Earplugs - to block noise while doing quizzes/tests on their mobile device in class

- Music - to listen to while completing independent work in class (e.g., YouTube, Spotify (Note 6) - a digital music service that gives access to millions of songs)

\section{To Assist Students with Low Vision}

- Seeing AI (Note 7) - app that converts documents to digital text (including reading money and signs) and narrates visual information about people, objects and scenes

- CamScanner (Note 8) - app that turns a smart phone into a mobile scanner. Images can be converted into text files using optical character recognition

- Screen readers (e.g., Envision (Note 9), JAWS (Note 10), Alma-Reader (Note 11), Zoom Text (Note 12))

\section{To Assist Students with Literacy Challenges}

- WordQ (Note 13) - spelling and grammar checker with word prediction

- $\quad$ Antidote (Note 14) - spelling and grammar checker in both English and French

\subsection{Appropriate Uses of Mobile Devices Out of Class}

Table 4 shows that both Canadian and Israeli students accessed course management systems and used office suites to work on assignments. Canadian students, but none of the professionals, indicated that they use their device to access online exams on the course management system and that they participate in course blogs. They, as well as Canadian professionals, also mentioned collaboration through students' use of their devices to access the Google Suite of apps, mainly Google Docs. Apart from a Canadian professional, only Israeli students mentioned that the devices are also used to schedule group meetings.

Table 4. Appropriate uses of mobile devices and apps out of class

\begin{tabular}{|c|c|c|c|c|}
\hline Appropriate Uses Out of Class & Canada & & Israel & \\
\hline & Students & Professionals & Students & Professionals \\
\hline Use Microsoft Office, Pages & $\mathrm{X}$ & & $\mathrm{X}$ & \\
\hline Check course management systems & $\mathrm{X}$ & & $\mathrm{X}$ & \\
\hline Access online library services & $\mathrm{X}$ & & $\mathrm{X}$ & \\
\hline Submit assignments online & $\mathrm{X}$ & & $\mathrm{X}$ & \\
\hline Read e-books & $\mathrm{X}$ & & $\mathrm{X}$ & \\
\hline Review course PowerPoint or Google Slides & $\mathrm{X}$ & & $\mathrm{X}$ & \\
\hline
\end{tabular}




\begin{tabular}{|c|c|c|c|}
\hline Listen to voice recording of PowerPoint & $\mathrm{X}$ & $\mathrm{X}$ & \\
\hline Watch videos posted by professors & $\mathrm{X}$ & $\mathrm{X}$ & \\
\hline Participate in course blog & $\mathrm{X}$ & & \\
\hline $\begin{array}{l}\text { Start writing essays on smartphone during } \\
\text { commute }\end{array}$ & $\mathrm{X}$ & & \\
\hline Dictate essays & $\mathrm{X}$ & & \\
\hline $\begin{array}{l}\text { Do research assignments (e.g., Google Search, } \\
\text { YouTube) }\end{array}$ & $\mathrm{X}$ & & $\mathrm{X}$ \\
\hline Use Turnitin & $\mathrm{X}$ & & \\
\hline Do exams on course management system & $\mathrm{X}$ & & \\
\hline $\begin{array}{l}\text { Use professor's PowerPoint to make flash cards } \\
\text { for studying }\end{array}$ & $\mathrm{X}$ & & \\
\hline $\begin{array}{l}\text { Provide proof of doing an activity (e.g., video of } \\
\text { exercise, selfie at a museum) }\end{array}$ & $\mathrm{X}$ & & \\
\hline $\begin{array}{l}\text { Share notes (e-mail, Facebook, WhatsApp, } \\
\text { course management system) }\end{array}$ & & $\mathrm{X}$ & $\mathrm{X}$ \\
\hline Search internet forums & & $\mathrm{X}$ & $\mathrm{X}$ \\
\hline Do calculations & & $\mathrm{X}$ & $\mathrm{X}$ \\
\hline Watch recorded lectures & & $\mathrm{X}$ & \\
\hline Schedule group meetings & $\mathrm{X}$ & $\mathrm{X}$ & \\
\hline $\begin{array}{l}\text { Use digital notebook/eportfolio (incorporates } \\
\text { text, images, recording, etc. - e.g., OneNote, } \\
\text { Padlet (Note 15)) }\end{array}$ & & $\mathrm{X}$ & $\mathrm{X}$ \\
\hline Create to-do list of assignments & & $\mathrm{X}$ & $\mathrm{X}$ \\
\hline Use Google Drive, Google Docs to collaborate & $\mathrm{X}$ & & \\
\hline Create video clip to answer questions & & & $\mathrm{X}$ \\
\hline
\end{tabular}

Some Canadian students used their devices to dictate essays and to start writing assignments on a smartphone during the commute to or from school, finishing the work on a laptop at home. Both groups of students mentioned using their devices to do additional research for assignments, including using their institution's online library services. Canadian students reported using their devices to access additional search websites, such as Google Search. Interestingly, this was referred to by Israeli professionals, but not by Israeli students. Although both Canadian and Israeli students reported using their devices to submit assignments online, only the Canadian students used the plagiarism software Turnitin (Note 16).

Both Canadian and Israeli students also used the professor's teaching materials on their device. For example, they reviewed course PowerPoint or Google Slides, read e-books, listened to audio recordings of lectures and watched videos posted online by professors. However, Canadian students used the professor's PowerPoint to make flash cards for studying, which the Israeli students did not mention. Canadian students used their devices to provide visual proof that they had completed an assignment (e.g., creating a video doing physical exercises, taking a selfie at a museum). It was interesting to find that both Israeli students and professionals indicated that students searched internet forums and shared notes using WhatsApp, email, Facebook, and the course management system; none of the Canadian participants spoke of this.

Israeli professionals noted two interesting uses of mobile devices at home: creating short videos instead of written text to respond to homework assignments and submitting digital notebook/e-portfolio assignments that incorporate text, images, recordings, etc. (e.g., OneNote, Padlet (Note 17)), an activity also mentioned by Israeli students. Israeli 
students were the only ones to refer to using their devices to watch recorded lectures. Israeli students also used their mobile devices as organizational tools. For example, they described using their device to create to-do lists of assignments. It is noteworthy that these organizational uses of mobile devices were also mentioned by Israeli professionals.

\section{Discussion}

The purpose of the present study was to examine the views of students with disabilities and of the professionals who work with them concerning how mobile devices and apps are used inside and outside the classroom. Focus group results from Canada and Israel reveal some similarities as well as differences. What is obvious is that mobile devices and apps are of extreme importance for students with disabilities both inside and outside the classroom. Although students use their devices for non-academic reasons in class, they also use them for academic purposes.

\subsection{Mobile Technologies and Students With Disabilities}

Consistent with the research of Chmiliar and Anton (2018), our findings indicate that students with disabilities use their mobile devices for all the same reasons as nondisabled students. For example, among inappropriate uses, students often text, check social media and do a variety of things on their devices, such as completing assignments for other courses and engaging in activities to alleviate boredom.

\subsubsection{Appropriate Uses in Class}

When it comes to appropriate uses of mobile devices in class, Google featured prominently among both Canadian and Israeli participants (e.g., research, translation, collaboration). Canadian students also used their devices to complete online quizzes and to respond to professor-initiated polling activities, such as Kahoot (Note 18) and Poll Everywhere (Note 19). It was not surprising that students in both countries used their devices to take notes, record lectures, take photos of diagrams and formulas on blackboards and whiteboards and of PowerPoint slides when these were not provided for download.

When the PowerPoint slides were made available for download, students tended to put them on their devices to follow along with the professor's presentation. This allows students with visual impairments to magnify elements of the information. Of course, this can be helpful for all students since PowerPoint slides are often projected using very small fonts.

While at times professionals noted some of the same uses as students, this was not true in all cases. For example, professionals did not mention students using students' devices to follow along with PowerPoint presentations or taking pictures of PowerPoint slides. However, professionals also noted some things that students did not mention, such as students using their devices to communicate with interactive whiteboards (e.g., Smart Boards), referring to e-books in class, taking notes directly on PowerPoint slides downloaded onto their devices, using peer evaluation and experimenting with augmented reality.

\subsubsection{Appropriate Uses Out of Class}

Interesting findings relate to appropriate uses of mobile devices out of class, mainly because professionals rarely think of applications that students indicated. For example, both Canadian and Israeli students accessed the professor's teaching materials on their devices (e.g., reviewed PowerPoint or Google Slides, listened to audio recordings of lectures, watched videos posted online by the professor, accessed online library services, checked the course management system, submitted assignments online and read e-books).

Although Canadian institutions have the technological capacity to provide recorded lectures to students, only the Israeli students mentioned viewing recorded lectures. This allows students to watch the video of the lecture when it is convenient for them, to watch the video as often as they wish and to pause the video as needed. As a result, students can focus on listening to the professor in class to gain a better understanding of the course material. Israeli students helped each other by sharing course notes using WhatsApp, email, Facebook, and the course management system, a practice which was recognized by the professionals. Canadian students did not use social media, e-mail or the course management system for this purpose. It is also interesting that Israeli participants indicated that students searched internet forums and created digital notebooks / e-portfolios, while none of the Canadian participants reported this. WhatsApp seemed to be more popular in Israel than Canada.

Canadian students used their devices to provide proof that they had completed an assignment. For example, students had to take selfies at designated locations or make short videos to complete assignments. Students also had to collaborate online to complete assignments; students used their devices for this online collaboration, (e.g., Google Docs, Zeetings (Note 20)). 
Canadian students used their smartphones on the commute to and from school to start working on written assignments using dictation. It is important that students be able to access the course management system and the institution's library remotely. Having remote access to course materials and the course management system allows students to use their devices to read course-related e-books, participate in course blogs, do online exams, and submit assignments online after they are run through Turnitin plagiarism software. Students also accessed the institution's online library services from home, in addition to using Google to do research.

\subsection{Using Mobile Devices as Assistive Aids}

Thirty years ago, in 1988, Mary Pat Radabaugh noted, "For most people technology makes things easier. For people with disabilities, however, technology makes things possible. In some cases, especially in the workplace, technology becomes the great equalizer and provides the person with a disability a level playing field on which to compete" (cited in National Center on Accessible Educational Materials, undated). This is still true today.

As noted by Chmiliar and Anton (2018), mobile technology devices and apps can serve as assistive technologies. This means that (1) the technology can compensate for a student's functional limitations related to their disabilities (e.g., read text aloud to a student who has low vision or poor reading comprehension) and (2) the technology can alleviate skill deficits (e.g., remedial reading software designed to improve phonic skills) (Stanberry \& Raskind, 2009). Here we focus on the former - mobile technologies that serve as assistive aids (i.e., that can be used to increase, maintain, or improve the functional capabilities of individuals with disabilities), whether these apps or devices are specifically designed for individuals with disabilities or are general use mobile technologies that can be used by students with disabilities as adaptive aids.

\subsubsection{Disability Specific Features and Apps}

Participants noted a variety of mobile device features and apps intended specifically for students with disabilities. Detailed in Table 3 these include turning off the device's notification system, installing a variety of apps that temporarily lock features of smartphones, apps that assist students with low vision, such as screen reading, scanning and optical character recognition, and apps for students with literacy challenges such as a grammar checker and a word prediction app.

\subsubsection{General Use Features and Apps}

In addition to the apps and techniques listed in Table 3, our results highlight that what are usually considered general use apps and built-in features of mobile devices are, in fact, used as assistive aids by students with certain disabilities (e.g., Fichten et al., 2013; Fichten, Asuncion, Barile, Fossey, \& De Simone, 2000). For example, the ubiquitous dictionary feature of most mobile apps can be used as assistive technology by students with literacy challenges and learning disabilities. The ability to dictate using mobile devices (speech-to-text/voice recognition) can be used by students with a variety of neuromuscular impairments and some types of learning disabilities. Text-to-speech screen reading technologies, both apps and built-in features of many mobile technologies, allow students with visual impairments and learning disabilities to read e-books and other documents.

The ability to record lectures and download PowerPoint slides permits students with visual impairments and learning disabilities to be attentive during class presentations while also having a record of the PowerPoint. In addition, students with certain disabilities, such as hearing impairments (these students may need to either look at the professor to lip read or at the sign language interpreter' hands and face) can focus on the lecture without having to look away to take notes. Being able to take photos of projected PowerPoint slides or of diagrams and formulas on the blackboard means that students with low vision can enlarge the content to see it more clearly.

When students can view a PowerPoint presentation on their device while the professor is presenting it in class, it facilitates the simultaneous viewing of slides and note taking. Students can follow along with the degree of magnification they require while at the same time taking notes using their app. Uploading a PowerPoint onto a device before class also permits students with learning disabilities or with hearing impairments to preview the upcoming lecture, allowing them to be better prepared. The availability of collaboration software, such as Google Docs, enables students with all types of disabilities to participate in the same way as their nondisabled peers.

Viewing recorded lectures not only allows students who failed to grasp a concept due to loss of attention during the lecture to review it, as might be the case with attention deficit hyperactivity disorder, but it also allows students who were unable to attend class to keep up-to-date. This could be due to a snow storm or a breakdown of the subway system as well as to hospitalization or fluctuating energy levels due to medical and psychiatric conditions. The same is also true of being able to submit assignments online. Accessing the school's online library means that students can complete assignments without having to travel back to their university for a missing article. But it also enables 
students with some complex or severe disabilities (e.g., neuromuscular and visual disabilities) to do literature searches without human assistance. We do not mean to disparage the importance of human assistance but rather promote the use of assistive technology which can allow individuals with disabilities to be more independent and productive.

As we noted earlier, approximately $50 \%$ of students with disabilities are not registered to receive disability related accommodations from their educational institution. Therefore, in many cases these students are left to cope on their own. Inexpensive general use and assistive technology apps and built-in features of mobile devices are likely to be of great utility for them.

\subsection{Limitations}

We need to note that the post-secondary institutions in the two countries were quite different as were the disabilities of the student participants. Moreover, although some professionals opined that students with and without disabilities used their mobile devices differently, they did not distinguish between the two groups in their responses. Also, sample sizes were small.

\subsection{Importance and Future Research}

Our study provides an important step in the exploration of the uses of mobile technologies by post-secondary students with disabilities. In particular, our findings point to the uses of mobile technology apps designed for the general public as adaptive aids for students with various disabilities. This highlights the importance of investigating universal design for higher education (UDHE) (Burgstahler, 2019) for mobile devices, as mobile learning is likely to be an important aspect of the future of post-secondary education. Further studies are needed to examine views of students with different disabilities and to include questions related to apps and mobile device features used, coping, support and satisfaction with students' mobile devices and apps and their ability to use them in the classroom. This research should include larger samples as well as mixed methods, including both in-depth interviews and objective questionnaires. It would also be interesting to examine the views of faculty and of nondisabled students.

The potential of mobile devices and apps to promote the success of students with disabilities in every aspect of their lives is still in the process of development. Future research needs to evaluate which apps and devices are efficient for learning both in and out of the classroom for students with diverse disabilities. It is important that new features of devices and apps be developed according to input by the students themselves. Such research is urgently needed since, as noted by Chmiliar and Anton (2018), students with disabilities would like to know what apps to use, how to use mobile apps to support their learning challenges and how to use mobile devices for learning.

\subsection{Implications}

Our results found that general use apps and features of mobile devices were often used as assistive aids by the students with disabilities in our focus groups, while other apps and features were mentioned by the participating professionals. Blurring of the division between assistive and general use technologies implies that large numbers of students with disabilities in post-secondary education could have access to a vast array of apps and devices from which to choose if they were made aware of their potential. These include the built-in functionality of mobile devices, such as effective dictation, magnification, and narration features, and inexpensive apps that are useful and usable by students with and without disabilities.

Extrapolating from past experience, a number of applications can be envisioned, or more likely have already been put to use by individuals outside our samples. For example, students with neuromuscular conditions and motor impairments could select those devices and apps that best address their functional limitations, such as large buttons, dictation apps and long ring tones. Students with visual impairments could also benefit from dictation apps to enter text but, in addition, they might be interested in VoiceOver or TalkBack - apps that read aloud what is on the screen. Individuals with hearing impairments could use the hearing aid compatibility features of smartphones, such as flashing or vibrating incoming call and text alerts or making headphones and earbuds mono to allow both ears to receive the same sound. Texting and video calling could permit individuals who use sign language or lip reading to communicate. For those with low vision there are features such as zoom and color inversion, along with screen color adjustment. Students with specific learning disabilities might find Speak Selection, an accessibility option that enables an iPhone to read back text, in addition to using dictation and predictive text features.

In addition, there are inexpensive or free apps for mobile devices that are either designed for individuals with specific functional limitations or simply work well for them. Examples provided by Malcolm and Roll (2017) include recording software, apps for note-taking, rendering the textbook into MP3 format, text-to-speech apps, writing and literacy apps, spelling, grammar and dictation apps, mind-mapping, proofreading with audio feedback, 
optical character recognition to convert certain non-text files formats into editable text, productivity software for time management and organization, as well as apps that display single words during reading.

In a recent investigation students with disabilities shared the types of mobile technology they currently use: these included reading and recording apps, taking pictures of the whiteboard, especially when numbers are involved, thereby allowing students to magnify the content to make it visible (Clouder et al., 2019). Students also used GPS apps for navigation and audio apps to listen to lectures at home. A recent paper by Chmiliar and Anton (2017) provides insight into the uses of mobile technologies that students with disabilities wish to have: technologies to read syllabi and course content; apps to check, write and submit assignments, as well as apps to check grades, take a quiz, post to a discussion forum, read discussion forum posts, communicate with instructors and other students, and read the textbook. Despite the variety of articles discussing the features and uses of mobile apps and devices, Cumming and Rodríguez (2017), in their meta-analysis of mobile tech supporting individuals with disabilities, concluded that, "research in the area has yet to establish a solid evidence base" (p 164).

In North America, there are already numerous listings of apps available for students with disabilities consisting of naming the "top 10" apps, etc. (e.g., Horowitz, 2013; Brisbin, 2016). For example, Ordinetz (undated) listed over 50 useful iOS or Android apps. Such lists are not necessarily helpful for students with disabilities, for even when they appear to be beneficial, the evaluations about what is and is not useful are usually made by "experts" and vendors, and not by individuals with disabilities themselves. It is because of this that the Adaptech Research Network has prepared edited lists of built in mobile device features and free and inexpensive apps that could be useful for students with disabilities. Evaluations are prepared by students with disabilities (http://adaptech.org/downloads/).

As Budd (2014) explained, it is most useful to group apps and mobile device features not by disability category, but rather by the functions of the apps or devices a student may need, regardless of their impairments, since students with different disabilities may benefit from similar types of apps. Moreover, people who have the same disability may not have the same needs. Many students have multiple disabilities, and a category which only includes apps for one of their disabilities will not necessarily be able to meet all their needs. The listings of mobile device features and apps in the Adaptech Research Network free and inexpensive database (http://adaptech.org/downloads/) can be of use to all post-secondary students, including those with diverse disabilities.

\section{Acknowledgements}

This work was made possible by an S051 Grant by Dawson College to Catherine Fichten. We are grateful to Dawson College and to our students: Maegan Harvison, Alex Lussier and Christine Vo.

\section{References}

Ableser, J., \& Moore, C. (2018, September 10). Universal Design for Learning and digital accessibility: Compatible partners or a conflicted marriage? Educause Review. Retrieved from https://er.educause.edu/articles/2018/9/universal-design-for-learning-and-digital-accessibility-compatible-partne rs-or-a-conflicted-marriage

Adams-Becker, S., Cummins, M., Davis, A., Freeman, A., Hall Giesinger, C., \& Ananthanarayanan, V. (2017). NMC Horizon Report: 2017 Higher Education Edition. The New Media Consortium. Retrieved from https://www.learntechlib.org/p/174879/

Advance HE. (2018, September). Equality and higher education: Students statistical report 2018. Retrieved from https://www.ecu.ac.uk/publications/equality-higher-education-statistical-report-2018/

Alkahtani, M., Ahmad, A., Darmoul, S., Samman, S., Al-zabidi, A., \& Matraf, K. B. (2016). Multitasking trends and impact on education: A literature review. International Journal of Social, Behavioral, Educational, Economic, Business and Industrial Engineering, 10(3), 987-993. Retrieved from https://waset.org/publications/10004600/multitasking-trends-and-impact-on-education-a-literature-review

Asuncion, J. V., Fichten, C. S., Ferraro, V., Barile, M., Nguyen, M. N., \& Wolforth, J. (2010). Multiple perspectives on the accessibility of eLearning in Canadian colleges and universities. Assistive Technology Journal, 22(4), 187-199. https://doi.org/10.1080/10400430903519944

Baker, W. M., Lusk, E. J., \& Neuhauser, K. L. (2012). On the use of cell phones and other electronic devices in the classroom: Evidence from a survey of faculty and students. Journal of Education for Business, 87(5), 275-289. https://doi.org/10.1080/08832323.2011.622814

Belardi, B. (2015, March). Report: New McGraw-Hill education research finds more than 80 percent of students use mobile technology to study. McGraw-Hill Education. Retrieved from 
http://www.prnewswire.com/news-releases/report-new-mcgraw-hill-education-research-finds-more-than-80-per cent-of-students-use-mobile-technology-to-study-300047130.html

Black, R. D., Weinberg, L. A., \& Brodwin, M. G. (2015). Universal design for learning and instruction: Perspectives of students with disabilities in higher education. Exceptionality Education International, 25(2), 1-26. Retrieved from https://ir.lib.uwo.ca/cgi/viewcontent.cgi?article=1131\&context=eei

Brisbin, S. (2016). Best Android apps for people with low vision. Access World Magazine, 17(2). Retrieved from https://www.afb.org/afbpress/pubnew.asp?DocID=aw170208

Brooks, D. C., \& Pomerantz, J. (2017, October). ECAR study of undergraduate students and information technology, 2017. EDUCASE Center for Analysis and Research. Retrieved from https://library.educause.edu/ /media/files/library/2017/10/studentitstudy2017.pdf

Budd, J. (2014). Why Adaptech does not categorize FANDI by disability type. Retrieved from http://adaptech.org/wp-content/uploads/Budd-2014-Why-Adaptech-does-not.pdf

Burgstahler, S. (2019, June). Effective models for the procurement, development, and use of accessible ICT in post-compulsory education: Personal perspectives. Paper presented at the 5th Ed-ICT International Network Symposium, Newport Pagnell, England.

CAST. (2018). Universal Design for Learning guidelines version 2.2. Retrieved from http://udlguidelines.cast.org

Chettri, S. (2016, June 8). Smartphones, hearing gear for students with disability. Hindustantimes. Retrieved from https://www.hindustantimes.com/delhi/smartphones-hearing-gear-for-students-with-disability/story-XUUjiivhM TVF96zbv5rTDO.html

Chmiliar, L., \& Anton, C. (2017). Students with disabilities: Mobile device ownership, usage, and perspectives on mobile learning. Proceedings of E-Learn: World Conference on E-Learning in Corporate, Government, Healthcare, and Higher Education (pp. 905-917). Vancouver, British Columbia: Association for the Advancement of Computing in Education (AACE).

Chmiliar, L., \& Anton, C. (2018). Mobile learning: Device ownership, usage, and perspectives of post-secondary students with and without disabilities. Journal on Technology and Persons with Disabilities, 6, 117-126. Retrieved from http://scholarworks.csun.edu/bitstream/handle/10211.3/202990/JTPD-2018-ID15-p117-126.pdf?sequence=1

Clouder, L., Cawston, J., Wimpenny, K., Mehanna, A. K. A., Hdouch, Y., Raissouni, I., \& Selmaoui, K. (2019). The role of assistive technology in renegotiating the inclusion of students with disabilities in higher education in North Africa. Studies in Higher Education, 44, 1344-1357. https://doi.org/10.1080/03075079.2018.1437721

Crompton, H., \& Burke, D. (2018). The use of mobile learning in higher education: A systematic review. Computers \& Education, 123, 53-64. https://doi.org/10.1016/j.compedu.2018.04.007

Cumming, T. M., \& Rodríguez, C. D. (2017). A meta-analysis of mobile technology supporting individuals with disabilities. The Journal of Special Education, 51(3), 164-176. https://doi.org/10.1177/0022466917713983

Eagan, M. K., Stolzenberg, E. B., Zimmerman, H. B., Aragon, M. C., Whang Sayson, H., \& Rios-Aguilar, C. (2017). The American freshman: National norms fall 2016. Los Angeles: Higher Education Research Institute, UCLA. Retrieved from https://www.heri.ucla.edu/monographs/TheAmericanFreshman2016.pdf

EDUCAUSE. (2019). Continuing to look to the horizon. Retrieved from https://library.educause.edu/resources/2019/4/2019-horizon-report

Fichten, C. S., Asuncion, J., Barile, M., Fossey, M. E., \& De Simone, C. (2000). Access to educational and instructional computer technologies for post-secondary students with disabilities: Lessons from three empirical studies. Journal of Educational Media, 25(3), 179-201. https://doi.org/10.1080/1358165000250303

Fichten, C. S., Havel, A., King, L., Jorgensen, M., Budd, J., Asuncion, J., .. Marcil, E. (2018). Are you in or out? Canadian students who register for disability-related services in junior/community colleges versus those who do not. Journal of Education and Human Development, 7(1), 166-175. https://doi.org/10.15640/jehd.v7n1a19

Fichten, C. S., Heiman, T., Havel, A., Jorgensen, M., Budd, J., \& King, L. (2016). Sustainability of disability-related services in Canada - Israel: Will the real universal design please stand up?. Exceptionality Education International, 26(1), 19-35. Retrieved from https://ir.lib.uwo.ca/cgi/viewcontent.cgi?article=1168\&context=eei

Fichten, C. S., Jorgensen, M., Havel, A., King, L., Harvison, M., Lussier, A., \& Libman, E. (2019). More than meets 
the eye: A Canadian comparative study on PowerPoint use among post-secondary students with and without disabilities. International Research in Higher Education, 4(2), 25-36. https://doi.org/10.5430/irhe.v4n2p25

Fichten, C. S., King, L., Jorgensen, M., Nguyen, M. N., Budd, J., Havel, A., ... Poldma, T. (2015). What do college students really want when it comes to their instructors' use of information and communication technologies (ICTs) in their teaching?. International Journal of Learning, Teaching and Educational Research, 14(2), 173-191. Retrieved from https://www.ijlter.org/index.php/ijlter/article/view/522/251

Fichten, C. S., Nguyen, M. N., King, L., Barile, M., Havel, A., Mimouni, Z., ... Asuncion, J. (2013). Information and communication technology profiles of college students with learning disabilities and adequate and very poor readers. Journal of Education and Learning, 2(1), 176-188. https://doi.org/10.5539/jel.v2n1p176

Fichten, C., Havel, A., Jorgensen, M., King, L, \& Harvison, M. (2019). Using students' personal mobile devices in class. Academic Matters, May 2019. Retrieved from https://www.dawsoncollege.qc.ca/academic-matters/article/using-students-personal-mobiledevices-in-class/?em ail=1)

Gagné, Y., \& Tremblay, D. (2019). Statistiques concernant les étudiants en situation de handicap dans les universités Québécoise 2017-2018. Association québécoise interuniversitaire des conseillers aux étudiants en $\begin{array}{lllll}\text { situation de } & \text { handicap } & \text { RQICESH). }\end{array}$ http://aqicesh.ca/docs/AQICESH_stat2017-2018-Sans-univ.pdf

Gooblar, D. (2014, January 23). Smartphones in the classroom? Let students decide. Chronicle Vitae. Retrieved from https://chroniclevitae.com/news/289-smartphones-in-the-classroom-let-students-decide

Hammer, R., Ronen, M., Sharon, A., Lankry, T., Huberman, Y., \& Zamtsov, V. (2010). Mobile culture in college lectures: Instructors' and students' perspectives. Interdisciplinary Journal of E-Learning and Learning Objects, 6, 293-303. Retrieved from http://www.ijello.org/Volume6/IJELLOv6p293-304Hammer709.pdf

Horowitz, B. T. (2013, April 30). 10 iPhone apps designed to assist the visually impaired. eWeek. Retrieved from http://www.eweek.com/mobile/10-iphone-apps-designed-to-assist-the-visually-impaired

Jorgensen, M., Fichten, C., King, L., \& Havel, A. (2018). Proceedings of the Ed-ICT International Network Montreal Symposium: Stakeholder Perspectives. Montréal, Québec: Adaptech Research Network. Retrieved from https://eric.ed.gov/?id=ED580147

Kuznekoff, J. H., \& Titsworth, S. (2013). The impact of mobile phone usage on student learning. Communication Education, 62(3), 233-252. https://doi.org/10.1080/03634523.2013.767917

Leyden, A. (2018, February 19). 40 uses for smartphones in school. Retrieved from https://www.goconqr.com/en/examtime/blog/40-uses-for-smartphones-in-school/

Malcolm, M. P., \& Roll, M. C. (2017). The impact of assistive technology services in post-secondary education for students with disabilities: Intervention outcomes, use-profiles, and user experiences. Assistive Technology, 29(2), 91-98. https://doi.org/10.1080/10400435.2016.1214932

Malka, V., Ariel, Y., Avidar, R., \& Chen Levy, E. (2014). The smartphone - students' new best friend? Analyzing the roles of smartphones in the lives of Israeli students. Paper presented at The $9^{\text {th }}$ Chais Conference on Research Innovation in Learning Technologies, Ra'anana, Israel. Abstract. Retrieved from https://www.openu.ac.il/innovation/chais2015/b3_6.pdf

McGuire, J. M., Scott, S. S., \& Shaw, S. F. (2003). Universal design for instruction: The paradigm, its principles, and products for enhancing instructional access. Journal of Postsecondary Education and Disability, 17(1), 10-20. Retrieved from https://files.eric.ed.gov/fulltext/EJ875999.pdf

National Center on Accessible Educational Materials. (undated). Assistive technology and AEM. Retrieved from http://aem.cast.org/navigating/assistive-technology.html

Nissan, Y. (2016, September 27). Survey: 90\% of Israelis use a smartphone for 7.4 hours a day [translation]. Globes Vision. Retrieved from https://www.globes.co.il/news/article.aspx?did=1001154647\&nagish=1

Ordinetz, S. (undated). Apps for higher ed. York College of Pennsylvania. Retrieved from https://www.ycp.edu/media/york-website/cpe/academic-advising/Apps-for-Students-with-Disabilities 
Park, K., Kim, H. J., \& So, H.-J. (2016). Are massive open online courses (MOOCs) really open to everyone? A study of accessibility evaluation from the perspective of Universal Design for Learning. Proceedings of HCI Korea 2016, 29-36. https://doi.org/10.17210/hcik.2016.01.29

Reid, G., Strnadovà, I., \& Cumming, T. (2013). Expanding horizons for students with dyslexia in the 21st century: Universal design and mobile technology. Journal of Research in Special Education Needs, 13(3), 175-181. https://doi.org/10.1111/1471-3802.12013

Scott, S. S., Loewen, G., Funckes, C., \& Kroeger, S. (2003). Implementing universal design in higher education: Moving beyond the built environment. Journal on Postsecondary Education and Disability, 16(2), 78-89. Retrieved from https://files.eric.ed.gov/fulltext/EJ875997.pdf

Snyder, T. D., de Brey, C., \& Dillow, S. A. (2016). Digest of education statistics 2015 (51st ed.) (NCES 2016-014). Washington, DC: National Center for Education Statistics, U.S. Department of Education. Retrieved from https://files.eric.ed.gov/fulltext/ED570993.pdf

Stanberry, K., \& Raskind, M. H. (2009). Assistive technology for kids with learning disabilities: An overview. Retrieved from http://www.readingrockets.org/article/assistive-technology-kids-learning-disabilities-overview

State of Israel, Ministry of Justice Report. (2012). Commission for Equal Rights of Persons with Disabilities [Hebrew]. Retrieved

from http://employment.jdc.org.il/sites/default/files/reseaarches/\%D7\%A9\%D7\%99\%D7\%9C\%D7\%95\%D7\%91\%2 0\%D7\%90\%D7\%A0\%D7\%A9\%D7\%99\%D7\%9D\%20\%D7\%A2\%D7\%9D\%20\%D7\%9E\%D7\%95\%D7\%92 \%D7\%91\%D7\%9C\%D7\%95\%D7\%AA\%20\%D7\%91\%D7\%9E\%D7\%95\%D7\%A1\%D7\%93\%D7\%95\%D7\% AA\%20\%D7\%9C\%D7\%94\%D7\%A9\%D7\%9B\%D7\%9C\%D7\%94\%20\%D7\%92\%D7\%91\%D7\%95\%D7\%94 \%D7\%94\%20\%D7\%A0\%D7\%99\%D7\%A8\%D7\%94\%20\%D7\%93\%D7\%A0\%D7\%92\%D7\%95\%D7\%A8.pdf

The Open University of Israel. (2018). The Open University of Israel Report (2017-2018). Retrieved from https://www-e.openu.ac.il/presidents-office/presidents-report.htm

The Room 241 Team. (2018, April 20). Driven to distraction: The device debate [Web log post]. Retrieved from https://education.cu-portland.edu/blog/classroom-resources/smartphones-in-classrooms/

Thomson, R., Fichten, C., Budd, J., Havel, A., \& Asuncion, J. (2015). Blending universal design, e-learning, and information and communication technologies. In S. E. Burgstahler (Ed.), Universal design in higher education: From principles to practice (2nd ed., pp. 275-284). Cambridge, Massachusetts: Harvard Education Press.

Tobin, T. J. (2016). Two radical shifts in how and why higher-education distance-learning administrators should promote universal design for learning. Proceedings of the Distance Learning Administration 2016 Conference, USA, 219-230. Retrieved from http://www.tiffanireardon.com/documents/2016-dl-proceedings-updated.pdf\#page=219

University of Waterloo. (undated). Managing students' use of technology in the classroom. Retrieved from https://uwaterloo.ca/centre-for-teaching-excellence/teaching-resources/teaching-tips/lecturing-and-presenting/lo gistics/laptops-classroom-virtue-or-vice

Wood. E., Zivcakova, L., Gentile, P., Archer, K., De Pasquale, D., \& Nosko, A. (2011). Examining the impact of off-task multi-tasking with technology on real-time classroom learning. Computers \& Education, 58(1), 365-374. https://doi.org/10.1016/j.compedu.2011.08.029

Xie, J., Basham, J. D., Marino, M. T., \& Rice, M. F. (2018). Reviewing research on mobile learning in K-12 educational settings: Implications for students with disabilities. Journal of Special Education Technology, 33(1), 27-39. https://doi.org/10.1177/0162643417732292

\section{Notes}

Note 1. https://www.snapchat.com/

Note 2. https://todoist.com/?lang=en

Note 3. https://www.forestapp.cc/

Note 4. https://play.google.com/store/apps/details?id=nefiginc.focuslockscreen\&hl=en

Note 5. https://www.mindlyapp.com/ 
Note 6. https://www.spotify.com/ca-en/

Note 7. https://apps.apple.com/ca/app/seeing-ai/id999062298

Note 8. https://www.camscanner.com/

Note 9. https://www.letsenvision.com/

Note 10. https://www.freedomscientific.com/products/software/jaws/

Note 11. https://www.almareader.com

Note 12. https://www.zoomtext.com/products/zoomtext-magnifierreader/

Note 13. https://www.quillsoft.ca/wordq5

Note 14. https://www.antidote.info/en/antidote-10

Note 15. https://padlet.com/

Note 16. https://www.turnitin.com/divisions/higher-education

Note 17. https://padlet.com/

Note 18. https://kahoot.com/

Note 19. https://www.polleverywhere.com/

Note 20. https://zeetings.uservoice.com/knowledgebase/articles/483864-what-exactly-does-zeetings-do 